participated in data collection, and contributed to the paper FOSF participated in the design and execution of the study, collected data, and discussed the interpretation of the findings. CMSM initiated the project, discussed ethical issues of the study and its design, collected data, and contributed to the paper. RAF participated in study design, data collection, and interpretation of results and contributed to the paper. RDGT initiated the formulation of the primary study hypothesis, discussed core ideas, and participated in the protocol design, analysis, and interpretation of the data and editing the paper. DAW initiated and coordinated the formulation of the main hypothesis, discussed core issues, participated in the design of the protocol, discussed the interpretation of the findings, and participated in the writing of the paper.

Funding: Promethazine and placebo were donated by Rhodia Farma Ltd. The study was supported by the Science and Technology for Development Programme of the European Community (Contract No TS3-CT91-0024).

Competing interests: None declared.

1 Fan HW, Cardoso JLC. Clinical toxicology of snake bites in South America. In: Meier J, White J, eds. Handbook of clinical toxicology of animal America. In: Meier J, White J, eds. Handbook of clinical tox:

2 Warrell DA, Looareesuwan S, Theakston RDG, Philips RE, Chanthavanish P, Viravan P, et al. Randomised comparative trial of three monospecific antivenoms for bites by the Malayan pit viper (Calloselasma rhodostoma) in southern Thailand: clinical and laboratory correlations. Am J Trop Med Hyg 1986;35:1235-47.

3 Cardoso JLC, Fan HW, Franca FOS, Jorge MT, Leite RP, Nishioka SA, et al. Randomized comparative trial of three antivenoms in the treatment of envenoming by lance-headed vipers (Bothrops jararaca) in São Paulo, Brazil. QJMed 1993;86:315-25.

4 Warrell DA, Davidson NMcD, Greenwood BM, Ormerod LD, Pope HM, Watkins BJ, et al. Poisoning by bite of the saw-scaled or caper viper (Echis carinatus) in Nigeria. QJ Med 1977;46:33-42.

5 Moran NF, Newman WJ, Theakston RD, Warrell DA, Wilkinson D. High incidence of early anaphylactoid reaction to SAIMR polyvalent snake antivenom. Trans R Soc Trop Med Hyg 1998,92:69-70.

6 World Health Organisation. Progress and characterization of venoms and standardization of antivenoms. WHO Offset Publication. Geneva: WHO, 1981:1-4. (No 58.)

7 Malasit P, Warrell DA, Chanthavanich AP, Viravan C, Mongkolsapaya J, Singhthong B, et al. Prediction, prevention, and mechanism of early (anaphylactic) antivenom reactions in victims of snake bites. $B M J$ $1986 ; 292: 17-20$
Key messages

- Antivenom therapy may cause early anaphylactic reactions

- Various drugs are used to prevent reactions, but none have been tested in randomised controlled studies

- This study showed that promethazine is not better than placebo at preventing early reactions

- Although most reactions are mild or moderate, trials of other drugs should be done to reduce frequency of anaphylaxis

8 Sutherland SK, Lovering KE. Use and adverse reactions over a 12-month period in Australia and Papua New Guinea. Med J Aust 1979;2:671-4.

9 Brian MJ, Vince JD. Treatment and outcome of venomous snake bite in children at Port Moresby General Hospital, Papua New Guinea. Trans $R$ Soc Trop Med Hyg 1987;81:850-2.

10 Cupo P, Azevedo-Marques MM, Menezes JB, Hering SE. Reações es de hipersensibilidade imediatas após uso intravenoso de soros antivenenos: valor prognóstico dos testes de sensibilidade intradérmicos. Rev Inst Med Trop São Paulo 1991;33:115-22.

11 Ministério da Saúde. Manual de diagnóstico e tratamento dos acidentes por animais peçonhentos. Brasilia: Fundação Nacional de Saúde, 1998.

12 Pocock SJ. Methods of randomization. In: Clinical trials. Chichester: John Wiley, 1983:66-89.

13 Armitage P. Pairing and randomization. Sequential experimentation. In Sequential medical trials. Oxford: Blackwell Scientific, 1972:21-3.

14 Wald A. Sequential analysis. New York: John Wiley, 1947.

15 Schwartz D, Flamant R, Lellouch J. Sequential trials. In: Clinical trials London: Academic Press, 1980:149-73.

16 Sutherland SK. Antivenom use in Australia. Premedication, adverse reactions and the use of venom detection kits. Med J Aust 1992;157:734-9.

17 Sutherland SK. Premedication before antivenom therapy. Med J Aust 1991;155:722.

18 Ford RM. Premedication before antivenom therapy. Med J Aust 1992;156:223.

19 Tiballs J. Premedication for snake antivenom. Med J Aust 1994;160:4-7.

20 Schwinghammer TL, Juhl P, Dittert LW, Melethil SK, Kroboth FJ, Chung VS. Comparison of the bioavailability of oral, rectal and intramuscula promethazine. Biopharmaceutics and Drug Disposition 1984;5:85-94.

21 Dachman WD, Bedarida G, Blaschke TF, Hoffman BB. Histamineinduced venodilation in human beings involves both $\mathrm{H}_{1}$ and $\mathrm{H}_{2}$ receptor subtypes. J Allergy Clin Immunol 1994;93:606-14.

\title{
The nuclear industry family study: linkage of occupational exposures to reproduction and child health
}

\author{
Noreen Maconochie, Pat Doyle, Eve Roman, Graham Davies, Peter G Smith, Valerie Beral
}

Concern about high rates of leukaemia and nonHodgkin's lymphoma among children and young adults living near certain nuclear establishments in the United Kingdom has led to a series of population based case-control studies. ${ }^{12}$ All these studies have investigated the possibility that the excesses were related to parental employment in those establishments, but the statistical power to detect anything other than extreme associations was very low owing to the rarity of employment in the nuclear industry (coupled with the rarity of the outcome). Moreover, if harmful parental occupational exposures were to exist it is unlikely that their effect would be restricted to cancer among workers' children; such exposures might be expected to influence a broader spectrum of reproductive problems, including infertility, miscarriage, and congenital malformations. These other aspects of reproduction remain largely unexplored.

The nuclear industry family study was set up to examine the occupational histories of a large cohort of nuclear industry workers in relation to all aspects of their reproduction and children's health. A full report of the methods is available on the BMJ's website.

\section{Subjects, methods, and results}

The survey population consisted of all employees of the Atomic Energy Authority, the Atomic Weapons Establishment, and British Nuclear Fuels who were in service at the time of the study, between 1993 and 1996 (8100, 6610, and 15550 workers respectively). Also included were past employees of the Atomic Energy Authority and British Nuclear Fuels who were aged under 75 years and who had an active or preserved pension administered by their joint pensions administration office (9678 and 6458 workers respectively). Of the survey population, $78 \%$ was male (36 342 workers).

Postal questionnaires were used to collect details of all reproductive attempts and the health of any children. Questions relating to periods of infertility were also included. Medical outcomes of interest were validated, with appropriate permission, by using clinical notes. Date of conception was estimated as the date of the end of pregnancy, minus gestational age, plus 14 days. Gestation was estimated as 40 weeks for most liveborn children (36 weeks or 28 weeks if
Papers p 1443 Correspondence to: Dr Maconochie n.maconochie@ lshtm.ac.uk continued over

BMJ 1999;318:1453-4 website extra

A full report of the methods of the study is available on the BMJ's website

www.bmj.com 
London School of Hygiene and Tropical Medicine, University of London, London WC1E 7HT

Noreen

Maconochie, lecturer

Pat Doyle, senior lecturer Graham Davies, research fellow

Peter Smith, professor

Leukaemia Research Fund, Institute of Epidemiology, University of Leeds, LS2 9LN

Eve Roman, reader

Imperial Cance Research Fund, University of Oxford, Radcliffe Infirmary, Oxford OX2 6HE Valerie Beral, professor prematurity was indicated) and was known for most incomplete pregnancies.

Information on employment and monitoring for exposure to ionising radiation was obtained from the three authorities and was computer linked to the data on reproduction and child health by using unique personal identification numbers. Parental preconceptional dose was estimated for each pregnancy.

Excluding the $7 \%$ (3068) questionnaires that were returned undelivered, the response rate for completed questionnaires was $82 \%$ for men and $88 \%$ for women. This adjusted response rate was uniformly high across authorities and by employment status. Only 1276 (3\%) workers refused to participate.

At the time of survey $67 \%$ men and $58 \%$ women returning a completed questionnaire had, or had attempted to have, children. Of these, $2 \%$ and $3 \%$ respectively had never achieved a pregnancy. Just under half had conceived (or attempted to conceive) their first pregnancy after starting work in the industry, and over $70 \%$ had been in continuous service at one site until either leaving the industry or date of survey. Characteristics of these workers, and of the 53672 completed pregnancies they reported, are presented in the table.

\section{Comment}

This is the first UK study to link detailed data on reproductive history to occupational information held by employers. Its design and conduct resulted in high quality data on a representative population of the workforces of the Atomic Energy Authority, Atomic Weapons Establishment, and British Nuclear Fuels. The response to the survey was extremely good, and a unique relational database has been created. This has enabled infertility, pregnancy, and child health outcomes to be examined with respect to parents' employment and dosimetry. The methods used in this study have been adapted for use in other important occupational investigations such as the study of reproductive outcome of veterans of the Gulf war.

We are grateful to all members of the study team at London School of Hygiene and Tropical Medicine, to our scientific steering group, and to all members of the industry who helped us. Most importantly, we thank the study participants themselves.

Funding: Department of Health and the Health and Safety Executive.

Contributors: NM (guarantor) participated in protocol development, data collection, analysis and writing the paper. PD participated in protocol design, data collection, analysis and writing the paper. ER initiated the research and participated in protocol design, data collection, analysis and writing the paper. GD participated in data collection and analysis. PS initiated the research and participated in protocol design and writing the paper. VB initiated the research and participated in protocol design and writing the paper.

Competing interests: PS has received funding from British Nuclear Fuels Ltd for research on the health of Sellafield workers.

1 Beral V, Roman E, Bobrow M, eds. Childhood cancer and nuclear installations.London: BMJ, 1993

2 Draper GJ, Little MP, Sorahan T, Kinlen LJ, Bunch KJ, Conquest AJ, et al. Cancer in the offspring of radiation workers: a record linkage study. $B M J$ $1997 ; 315: 1181-8$

(Accepted 21 April 1999)
Characteristics of workers reporting ever having attempted to have children, and of their pregnancies and liveborn children. Values are numbers (percentages) unless otherwise specified. Definitions and explanations will be found in the tables on the $B M J$ website

\begin{tabular}{|c|c|c|}
\hline & $\begin{array}{l}\text { Male workers } \\
(\mathrm{n}=18 \mathrm{744})\end{array}$ & $\begin{array}{c}\text { Female workers } \\
(n=4 \text { 702) }\end{array}$ \\
\hline \multicolumn{3}{|l|}{ Characteristics of workers } \\
\hline Mean (SD) age at survey (years) & $50.9(13.6)$ & $46.1(12.6)$ \\
\hline \multicolumn{3}{|l|}{ Most recent authority of employment: } \\
\hline Atomic Energy Authority & 7331 (39) & $2115(45)$ \\
\hline Atomic Weapons Establishment & $2442(13)$ & $815(17)$ \\
\hline British Nuclear Fuels Ltd & $8971(48)$ & $1772(38)$ \\
\hline \multicolumn{3}{|c|}{ Year of first employment by AEA, AWE, BNFL: } \\
\hline$<1970$ & 7047 (38) & $672(14)$ \\
\hline $1970-79$ & $5765(31)$ & $1483(32)$ \\
\hline $1980-96$ & $5932(32)$ & $2547(54)$ \\
\hline $\begin{array}{l}\text { Median (range) length of employment } \\
\text { (years) }\end{array}$ & $17.3(0.01-46.6)$ & $9.7(0.2-47.2)$ \\
\hline Ever monitored before survey & $15402(82)$ & $1333(28)$ \\
\hline At least one pregnancy & $18416(98)$ & $4579(97)$ \\
\hline $\begin{array}{l}\text { Mean (SD; range) No of pregnancies } \\
\text { reported per worker }\end{array}$ & $2.4(1.1 ; 1-13)$ & $2.2(1.1 ; 1-8)$ \\
\hline At least one live birth & $18131(97)$ & $4435(94)$ \\
\hline $\begin{array}{l}\text { Mean (SD; range) No of live births re } \\
\text { per worker }\end{array}$ & $2.2(1.0 ; 1-15)$ & $2.0(0.9 ; 1-7)$ \\
\hline
\end{tabular}
per worker

\begin{tabular}{|c|c|c|}
\hline Pregnancies & $(\mathrm{n}=43710)$ & $(n=9962)$ \\
\hline \multicolumn{3}{|l|}{ Year of pregnancy end: } \\
\hline$<1965$ & $15172(35)$ & 3080 (31) \\
\hline $1965-74$ & $10138(23)$ & $2648(27)$ \\
\hline $1975-84$ & $9596(22)$ & $1698(17)$ \\
\hline $1985-96$ & $8804(20)$ & $2536(25)$ \\
\hline $\begin{array}{l}\text { Parent ever employed before estimated date } \\
\text { of conception }\end{array}$ & $23962(55)$ & $3634(36)$ \\
\hline $\begin{array}{l}\text { Parent ever monitored before estimated dat } \\
\text { of conception }\end{array}$ & e $17873(41)$ & $959(10)$ \\
\hline \multicolumn{3}{|c|}{$\begin{array}{l}\text { Parental lifetime cumulative whole body dose (mSv) prior to estimated date of } \\
\text { conception: }\end{array}$} \\
\hline Never monitored & 25837 (59) & $9003(90)$ \\
\hline \multicolumn{3}{|l|}{ Monitored: } \\
\hline $0-$ & $7936(18)$ & $684(7)$ \\
\hline $10-$ & $6241(14)$ & $244(2)$ \\
\hline $50-$ & $1836(4)$ & $19(0.2)$ \\
\hline $100-$ & $1591(4)$ & $1(0.01)$ \\
\hline $500 \mathrm{mSv}$ or more & $14(0.03)$ & 0 \\
\hline Uncertain & $255(0.6)$ & $11(0.1)$ \\
\hline Median (range) & $12.6(0-1167.2)$ & ) $4.2(0-122.4)$ \\
\hline Liveborn children & $(n=39557)$ & $(n=8 \quad 883)$ \\
\hline $\begin{array}{l}\text { Mean (SD; range) age of living children at } \\
\text { survey (years) }\end{array}$ & $\begin{array}{c}22.8 \\
(13.0 ; 0.01-58.4) \\
\end{array}$ & $\begin{array}{c}21.6 \\
(12.9 ; 0.02-56.7) \\
\end{array}$ \\
\hline \multicolumn{3}{|c|}{$\begin{array}{l}\text { Parental monitoring prior to age } 25 \text {, death or survey (including prior to } \\
\text { conception): }\end{array}$} \\
\hline $\begin{array}{l}\text { Never employed or monitored at any } \\
\text { time }\end{array}$ & $854(2)$ & $553(6)$ \\
\hline Never monitored & $7180(18)$ & $6130(69)$ \\
\hline $\begin{array}{l}\text { Monitored preconceptionally, never } \\
\text { monitored after birth }\end{array}$ & $1409(4)$ & $387(4)$ \\
\hline $\begin{array}{l}\text { Monitored both preconceptionally and } \\
\text { after birth }\end{array}$ & 14489 (37) & $414(5)$ \\
\hline $\begin{array}{l}\text { Never monitored preconceptionally, } \\
\text { monitored after birth }\end{array}$ & $15625(40)$ & 1399 (16) \\
\hline \multicolumn{3}{|c|}{$\begin{array}{l}\text { Parental lifetime cumulative whole body dose (mSv) prior to estimated date of } \\
\text { conception: }\end{array}$} \\
\hline Never monitored & $23659(60)$ & $8082(91)$ \\
\hline \multicolumn{3}{|l|}{ Monitored: } \\
\hline $0-$ & $7131(18)$ & $567(6)$ \\
\hline $10-$ & $5508(14)$ & $204(2)$ \\
\hline $50-$ & $1623(4)$ & $19(0.2)$ \\
\hline $100-$ & $1396(4)$ & $1(0.01)$ \\
\hline $500 \mathrm{mSv}$ or more & $10(0.03)$ & 0 \\
\hline Uncertain & $230(0.6)$ & $10(0.1)$ \\
\hline Median (range) & $12.4(0-1167.2)$ & $4.3(0-122.4)$ \\
\hline
\end{tabular}

